\title{
(UN)STITCHING THE MEMORY AND THE STORY OF A MELANOMA: GIVING A FORM TO FORGETFULNESS BETWEEN ANTHROPOLOGY AND CREATIVE ETHNOGRAPHIC DRAWING
}

Susana de Noronha ${ }^{1}$

CES, Coimbra, Portugal

The visual essay and triptych "Erase the past; It's over; Move on" is the result of an anthropological analysis of the cancer experience of a Portuguese woman, "Violeta", whose story is told by her daughter "Flor", thirty years after her death. Blending embodied knowledge, oral narrative, anthropology and scientific illustration, enhanced by metaphor and imagination, the use of creative ethnographic drawing gives a shape to the undivided processes of memory and forgetfulness pervading this narrative. Using drawing as a methodological resource, this bybrid exercise involves a balanced mixture of speech, text, and image, grounded in the words of the interviewed woman. It suggests an ontological, epistemological and performative understanding of the artistic and visual practices of illustration, using them as extensions of knowledge and action, enlarging the way we can understand and act on the impacts of illness and death, and (un)making memory. "Flor" agreed to tell the story, but she does not want to remember the experience: her resistance strategy was based on forgetting and erasing the past. The set of three drawings conveys this difficult process of rebuilding one's memory out of fragments, but also the will to lose it again, breaking the thread that unites them.

Keywords: cancer, death, memory, forgetfulness, ethnographic drawing

Susana de Noronha, an anthropologist with a Ph.D. in sociology, is a researcher at the Centre for Social Studies (CES), University of Coimbra, Portugal. Winner of the 2007 CES Award for Young Portuguese-speaking Social Scientists, and of the 2003 Bernardino Machado Award for Anthropology from the University of Coimbra. As a writer and researcher, she is also a published lyricist and an author of scientific illustrations, using photography, painting and creative ethnographic drawing. Contact email: susananoronha@ces.uc.pt. 

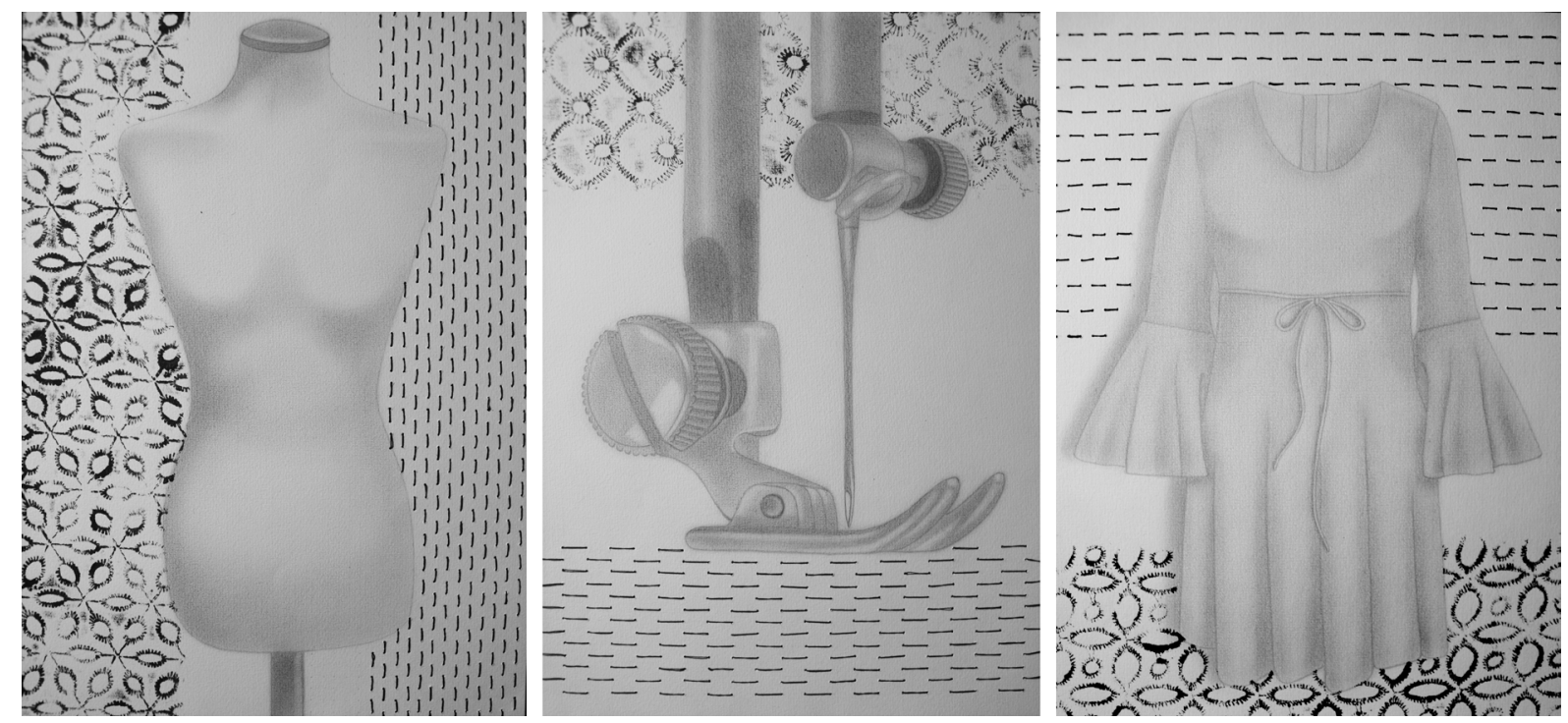

"Erase the past; It's over; Move on." Graphite, charcoal, acrylic and sewing thread on paper. Susana de Noronha \&"Flor", 2017.

\section{PROCESS: THEORETICAL AND METHODOLOGICAL APPROACH}

Cancer and death leave different marks on the bereaved relatives, in their feelings of pain and their ways of resisting. Speaking about the deceased, remembering and making them present, sustaining the connection, both oppress and give comfort, reduce and intensify their suffering (Foster 2011). Traumatic experiences punctuated by moments of extreme suffering and pain can become unspeakable facts, in stories interspersed with silences and hiatuses, pointing to the selectivity of memory and expression (Good 1994). Memory and forgetfulness are intertwined in the way we access the past and experience the present, using relevant details and forgetting the rest (Forty 1999). Past, memory and narrative are always fluid realities, made or undone according to the circumstances and motivations of those who give them form and substance (Forty 1999). Can anthropology and creative ethnographic drawing, grounded in the lived experience and embodied knowledge of a woman, make sense of forgetfulness, and act (Bell 2006; Noronha 2009) against the effects of cancer and death, undoing memory?

This essay is the result of an anthropological investigation that gathered and addressed the stories of Portuguese women with different cancer experiences (Noronha 2019), analysing how illness is experienced and conceptualized, from the disruptive effects of cancer to the coping strategies and agency of those who face it. ${ }^{2}$ Regarding "Flor", the interview took the form of an informal conversation, allowing the interviewed woman to guide the emerging story, avoiding predefined questions and expected answers. The conversation was audio recorded and subsequently transcribed, with attention to the elements stressed by the interviewee. Starting from her experience and knowledge, I wrote a "text with things inside", embedding in it a visual

2 This article results from a postdoctoral research project developed at the Centre for Social Studies (CES), University of Coimbra, and it has benefitted from the funding schemes and support of the Portuguese Foundation for Science and Technology under the Strategic Project (UID/SOC/50012/2019); the Transitional Rule (DL57/2016/CP1341/CT0012); and under the Human Capital Operational Programme (HCOP), supported by the European Social Fund and by national funds of the Ministry of Science, Technology and Higher Education, Portugal (MCTES) - postdoctoral fellowship and research project Ref.: SFRH/BPD/88239/2012. 
essay, using drawing to show realities that writing alone cannot grasp. Blending speech, text and image in an undivided and balanced synthesis, it develops from the story and the woman who tells it, giving form to her words. Resulting from our conversation, based on the moments, memories, and objects mentioned by "Flor", the triptych pictured in this text is understood as a co-authored creation, taking the name of my interlocutor, seeking to balance speech and writing, interviewee and researcher. Its title also came from her mouth, a phrase that sums up and explains her experience.

To rewrite and to draw her story, I also aimed to reshape and rethink the concept and practice of scientific illustration, enhancing it with imagination and metaphor. The ambition was to recover (Azevedo 2016) and reinvent ethnographic drawing, applying a different set of rules, showing that a creative and metaphorical version is not incompatible with factual reality or with scientific writing. Creative methodologies can broaden the way anthropology understands and acts on reality while remaining an objective, valid, and theoretically robust form of knowledge. By refusing to see them as merely appended or marginal, I affirm the artistic and visual practices of illustration as realities that can be embedded in science, taking advantage of their ontological (Marques 2017; Noronha 2009), heuristic, epistemological and performative resources (Gell 1998; Noronha 2009). Linking the anthropology of illness (Mattingly 2001) to the possibilities of a hybridization of ethnography, art (Campos 2012; Schneider 2005) and visual methods (Banks 2015), with emphasis on drawing (Escallier, 2016; Gomes 2016), I emphasize what we can find by mixing them, broadening the way we can reflect and act on illness, death and painful memories (Noronha 2015).

In order to work with a paper format common to anthropology and drawing, and since the format for research work is usually between 21 and 29.7 centimetres, all images were created on A4 paper, which thus acted as a material and symbolic link between the two disciplines and practices. Regarding colour, I used black, white, and the greys in between, since they define one of the central points of the story, but are also the colours of written science, of its books, words and pages, and transfer the same chromatic matrix onto the sheets of drawing paper. I used five materials: paper, graphite, charcoal, acrylic paint, and sewing thread applied with a needle - materials that I am skilled in - mixing them to reflect a materiality that is important in the interviewee's story. But who are the two women behind this essay, and what reflections can we draw from the blend of embodied, anthropological and creative knowledge?

"Violeta", a married housewife, mother of two, died in 1984, never knowing she had cancer. A skin mole that had grown rapidly on her face was removed, analysed, and diagnosed as a metastatic melanoma, beyond any possible treatment. The doctor and her husband never told her of the diagnosis. Illness and death were experienced at home, without hospitals. In the first and third person, "Flor", the daughter, tells a story that is also hers. "Flor" shared thirteen years with her mother: she is now over forty. "Violeta" was thirty-six: she died more than thirty years ago. Memories are scarce and hard to assemble. "Flor" remembers the mole on her mother's face, but she has no memory of exams, medical appointments or surgeries. It was her family who told her what she knows about the disease, months or years after the incident. "Flor" speaks of memories she does not have, that have not been shared, of memories she lost in time, and of those she wanted to forget. We cannot grasp "Violeta's" experience, but we can learn from the story told by "Flor" what she did to silence death and pain, and to forget cancer, after losing mother and memories. 


\section{"FLOR" AND HER WORDS: WHAT REMAINS (EMPTY)}

"On that day, I was at school. I was in the eighth grade. At that time, I already knew how to sew. All I learned about sewing was by myself. I looked at an outfit, I thought I could do it... and I'd do it! So, I had sewn a pair of white trousers with black thread. I had no white thread. I put the trousers on, but they were so tight that the threads began to break, and the black started to show. How ridiculous... at the school break. I went back home and convinced my friend to come with me. We skipped a class so I could change my trousers. [...] When I was coming out of my room, my father said this to me... - Your mother has died! I do not know how I reacted... I was... I don't know. Then they made me go in, into the bedroom... it was the worst experience I've ever had in my life! When I entered, my mother was purple! That image! I just wanted to leave the house! I was thinking... this is a dream, I'm going to wake up and nothing of this ever happened! [...]

Whenever I went to bed at night, one thing I thought about was... ok, she died! So, if this isn't a dream, I only want to wake up twenty years from now, because when I wake up, since so much time has passed, I'll no longer have the pain I'm feeling at this moment. [...] My brother, poor boy! I feel a very deep sorrow, I did not pay attention to him at that time. I was so obsessed with forgetting my own situation that I even forgot that he was also... I remember he entered my room and said... - what about from now on, how will it be? I couldn't bear to hear his words, because I did not want anyone to say anything. I did not want to know, I did not want to talk about it. For me, it had happened, it was over! I dealt with the situation in this way, that was it, I never talked about it again, never, ever! [...]

My mother left behind an incredible collection of clothes. I asked my dad to give everything away, I wanted to get rid of everything! I wanted to forget the whole situation. My explanation is that I wanted to forget that moment. It's shocking! The clothes... no doubt about it! It was hard to open the closet, to see the clothes there, and not seeing the person who wore those clothes. I can still see that image... this situation really affected me. [...] I think it was my father who kept it in their closet, not me. Then I moved it to my room. It's still there! I never gave it away. It's a seventies dress, with a very interesting design. It's violet... purple, lilac, printed. [...] Maybe I got to try it on, I don't know if it fits me now, with my shape. I never wore it. It's not ugly, but you look at it, with that fabric, and you see it's from the seventies. But I really like the pattern. I've been thinking of copying the pattern and making a new dress with another fabric. [...]

This conversation we are having is what is left! As I say, I don't have much to tell. It's just a selective memory, glimpses I still have. Maybe I also make and have made an effort to forget. There are things that I am telling you about that I didn't even remember. And many things that I cannot remember because, maybe, I insisted on forgetting them. The outstanding ones turn out to be harder to forget. [...] I don't remember much because I detached myself from all of it. In order to protect myself, I kept detached and I continue to try to distance myself from the situation. [...] Let bygones be bygones. Erase the past, it's over, move on! At that time, I wanted to forget. And because I never tried to keep those memories, things just got erased. They're gone!" ("Flor", 44 years old) 


\section{DRAWING FORGETFULNESS, LEAVING THE STORY BETWEEN THE LINES}

There are many forms of forgetfulness: ones that happen and ones that are sought and created. To resist an emptied life and family, to forget her mother's melanoma and death, "Flor" silenced the three words: she did not talk about the situation, she wanted to put everything aside and let time pass. To rebuild herself and feel whole, she forgot many things and insisted on disremembering others. But there are things that cannot be forgotten, even if you want to: they remain forever, even after time passes and feelings change. Between preserved, lost, and forgotten memories, the "violet... purple, lilac" dress, its colour undefined, still hangs nearby. Left in a closet, it's still new, it's still "Violeta's", it's her size and has her patina, the only person who wore it. "Flor" thought about making a replica of the dress, as she likes the pattern but finds the printed fabric dated and odd. "Flor" likes clothes, and she has always been fond of sewing, buying, and wearing them. She is a teacher, but she keeps a sewing machine and a dressmakers dummy. When she finds time, she still makes some clothes, with black or coloured thread.

To depict the story of "Violeta" and "Flor", I brought together the dressmakers dummy, the sewing machine, and the dress, restating the daughter's wish, "Erase the past; It's over; Move on." The drawings in the triptych are a collage of the past and the present, along with a version of the life that was never finished. I gave the drawings a naïve contour, like things out of the life and story of a little girl who is still small, still a child. Using the paper as white fabric, I pierced it with a needle and sewing thread, stitching together thirteen black seams, the number of misfortune, and the age she had at that time. The black thread evokes the piece of clothing made and worn by "Flor", the pair of trousers that impelled her to return home on a school day, the day of her mother's death, when the stitched seams on the fabric imitated life, also failing. The black lines are a moment and memento of what "Flor" has never been able to forget, "the worst experience of her life", kissing her purplish cold mother, and the arrival of loneliness.

The dress is the only object and piece of clothing that the family has kept; it is thirty years old but it does not leave the house, remains suspended in time, hanging in a closet. When I ponder over the empty dress with no woman in it, I remember "Flor's" dressmakers dummy, often undressed, a body of cloth without head or legs, standing on one foot. In order to give them form, I photographed the two objects, asking "Flor's" permission to have a few minutes to observe them in detail, before transferring them into shapes made of graphite and charcoal powder. Comparable to a ready-to-wear second skin, the dress evokes the long organ lined with cancer, covering the body from head to toe, beautiful on the outside, but internally distorted, imperceptibly diseased. The empty dress, like any piece of unused clothing, is a metaphor for those who have become spirit, without form or warmth. In the thirty years that have passed, everything has changed, only the dress remains the same, new and undamaged, more complete than any memory. The dressmakers dummy still waits for the outfit from the seventies, in a different fabric and colour. With a needle and thread, or a sewing machine, "Flor" could make that second dress, using the pattern in a different way. Until then, separated but corresponding in size, dress and dummy complete each other in what they lack, a frock without an owner, a body without any clothes.

Using the image of a sewing machine at a standstill, having run out of thread, the triptych gives shape to the difficulty of rebuilding a memory, giving it meaning. "Violeta" and her cancer are a patchwork of reminiscences, filled with holes, loose threads that do not tell a complete 
story. The decision not to (re)make the dress is also a choice of not to disturb the past, of quieting memories, "forgetting and moving forward", sewing whatever comes next. Handmade, without a sewing machine, the thirteen sequences of stitches also refer to this suspended task, to everything that was left aside, undone or unfinished. The three fabric surfaces printed with acrylic paint on the paper are variations of the same floral, childlike texture, referring to this opening of possibilities, to the choice between whitening the past, creating a blank space, already erased, or painting it with renewed shapes, remembering, speaking, sharing the story, giving form to a new dress. At the same time, the sewing machine also represents another means of creating memory and action, bringing "Flor" and me together: spoken words, written texts, stitches, paint, and drawings, unfolding cancer and knowledge, reaching out to others with an experience at second hand.

\section{CONCLUSIVE IMAGES}

The metastatic melanoma overpowered more than one woman: it changed her children, her family, and their entire lives, leaving a growing emptiness in the memories and objects left behind. Knowing how cancer is experienced and conceptualized is only possible when illness becomes a story, lived and narrated as shared experience. How did an orphaned child, now a woman, experience illness and death in her own family? In the transition from experience to expression, how are the disease and the deceased woman reconstructed, in mnemonic and narrative? The melanoma does not emerge as the most significant element in the story told in this essay: rather, death and loss are the matrix of "Flor's" embodied experience and account. By combining creative ethnographic drawing with anthropological reasoning, while analysing this story, we understand that creating meaning and control over an extreme and unexpected experience of illness, pain, and loss, can also entail a rejection of narrative, resorting to silence and forgetfulness, suppressing conversations and dismantling recent memories, wanting to mitigate suffering and erase the past. Two of the triptych's drawings, the sewing machine and the dummy, emphasise the world of the daughter, helping to forget the "violet... purple, lilac" dress, rebuilding life with new fabrics, sewing ahead, never looking back.

\section{BiBLIOGRAPHY}

Azevedo, Aina. 2016. "Desenho e antropologia: recuperação histórica e momento atual" Cadernos de Arte e Antropologia 5(2)-1:15-32.

Banks, Marcus and David Zeitlyn. 2015. "Making Images." Pp. 106-128 in Visual Methods in Social Research. Thousand Oaks: Sage Publications.

Bell, Susan E. 2006. "Living With Breast Cancer in Text and Image: Making Art to Make Sense." Qualitative Research in Psychology 3(1):31-44.

Campos, Ricardo and Peter Anton Zoettl. 2012. "Arte e Antropologia? Para Uma Espécie de Introdução..." Cadernos de Arte e Antropologia 1(1)-1:5-8.

Escallier, Christine. 2016. "De l'objet intrinsèque à la pensée technique: le rôle médiateur du dessin en ethnographie maritime" Cadernos de Arte e Antropologia, 5(2)-1:49-73.

Forty, Adrian and Susanne Kuchler, eds. (1999) The Art of Forgetting. Oxford: Berg. 
Foster, Terrah L., Mary Jo Gilmer, Betty Davies, Mary S. Dietrich, Maru Barrera, Diane L. Fairclough, Kathryn Vannatta and Cynthia A. Gerhardt. 2011. "Comparison of Continuing Bonds Reported by Parents and Siblings After a Child's Death From Cancer." Death Studies 35(5):420-440.

Gell, Alfred. 1998. Art and Agency: An Anthropological Theory. Oxford: Clarendon Press.

Gomes, Inês Belo. 2016. "Deixei o desenho enterrado ou como ressuscitar o grafismo enquanto metodologia antropológica: um caso prático" Cadernos de Arte e Antropologia 5(2)-1:75-90.

Good, Mary-Jo DelVecchio, Paul Brodwin, Byron J. Good and Arthur Kleinman, eds. 1994. Pain as Human Experience: An Anthropological Perspective. Berkeley, CA: University of California Press.

Marques, Sandra C. S. and Ricardo Campos. 2017. "Políticas de Visualidade, Práticas Visuais e a Construção de Espaços de Imaginação.” Cadernos de Arte e Antropologia 6(2)-1:5-10.

Mattingly, Cheryl and Linda C. Garro, eds. 2001. Narrative and the Cultural Construction of Illness and Healing. Berkeley, CA: University of California Press.

Noronha, Susana de. 2009. A Tinta, a Mariposa e a Metástase: A Arte Como Experiência, Conhecimento e Acção Sobre o Cancro de Mama. Porto: Edições Afrontamento.

Noronha, Susana de. 2015. Objetos Feitos de Cancro: Mulheres, Cultura Material e Doença nas Estórias da Arte. Coimbra: Almedina.

Noronha, Susana de. 2019. Cancro sobre Papel: estórias de oito mulheres portuguesas entre palavra falada, arte e ciência escrita. Coimbra: Almedina.

Schneider, Arnd and Christopher Wright, eds. 2005. Contemporary Art and Anthropology. Oxford: Berg. 